\title{
An Analysis of Interstitial Keratitis Secondary to Epstein-Barr Virus
}

\author{
Carl Pellerin, BS, Ethan Thibodeaux, BS, Zhenyang Zhao, MD and Yusra Siddiqui, MD*
}

Department of Ophthalmology, University of Texas Medical Branch, TX, USA

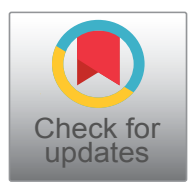

*Corresponding author: Yusra Siddiqui, Department of Ophthalmology, University of Texas Medical Branch, 700 University Blvd, Galveston, TX 77555, USA

\begin{abstract}
Epstein-Barr Virus (EBV), also known as human herpes virus 4 , is a DNA virus that causes a range of pathologies. Interstitial keratitis (IK) is a rare manifestation of EBV that is seldomly characterized in the literature. To our knowledge, a review of the clinical presentations and reported treatments of EBV IK has not been conducted. Here, we report a case of EBV IK in a patient and review 14 cases in the literature. The differential diagnosis and identifying clinical characteristics of EBV IK, diagnostic methods used to confirm EBV, and effective treatments are discussed.
\end{abstract}

\section{Keywords}

Interstitial keratitis, Stromal keratitis, Epstein-Barr virus, EBV, Mononucleosis

\section{Introduction}

Epstein-Barr virus (EBV), also known as human herpes virus 4 , is a DNA virus that is highly prevalent with approximately $90 \%$ of adults producing antibodies to EBV antigens [1]. This virus is responsible for many conditions ranging from infectious mononucleosis to severe cancers. EBV infection has also been associated with several ocular conditions: Conjunctivitis, dry eye, oculoglandular syndrome, keratitis, uveitis, choroiditis, retinitis, papillitis, and ophthalmoplegia [1].

Interstitial keratitis (IK) encompasses any non-ulcerating inflammation and vascularization of the corneal stroma. Subsequent scarring of the cornea may lead to significant vision loss [2]. IK accounts for 3\% of keratoplasty operations in the United States [2].

In the past decade, herpes simplex virus (HSV) surpassed syphilis as the most common etiology of IK in the United States, accounting for $35.1 \%$ of cases [3]. Epstein-Barr Virus (EBV) accounts for significantly fewer cases of IK and is often undiagnosed. Here, we present a case of IK secondary to EBV infection. The characteristic of our case along with 14 previous cases in the literature are summarized to identify common features of EBV-related IK.

\section{Methods}

Databases were queried for case reports of IK secondary to EBV published in English between January 1940 and January 2020. Keyword combinations of "interstitial keratitis", "stromal keratitis", "Epstein-Barr virus", "EBV", "mononucleosis" were used. In total, 7 articles were retrieved and 14 cases identified. We excluded any case presentations that had concomitant infections which may also impact the eye(s). Additionally, any case that involved damage to the corneal epithelium and/or endothelium was removed. The remaining case presentations were analyzed for patient age, ocular symptoms, corneal manifestations, treatment and resolution, lasting visual consequences, and serological test results.

\section{Case Report}

A 39-year-old female with no significant past medical history presented with bilateral blurred vision, eye pain, and photophobia. The symptoms started 6 months prior with a white dot in the left eye, which progressively enlarged. Similar presentation was later noticed in the right eye. She denied trauma, contact lens use, or preexisting ocular conditions. Best corrected visual acuity (BCVA) was 20/40 in right eye (OD) and 20/80 in left eye (OS).

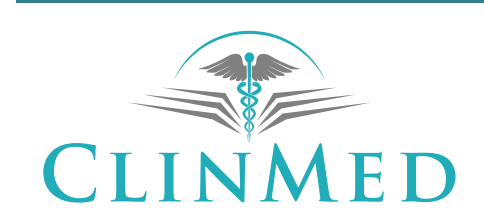

INTERNATIONAL LIBRARY 


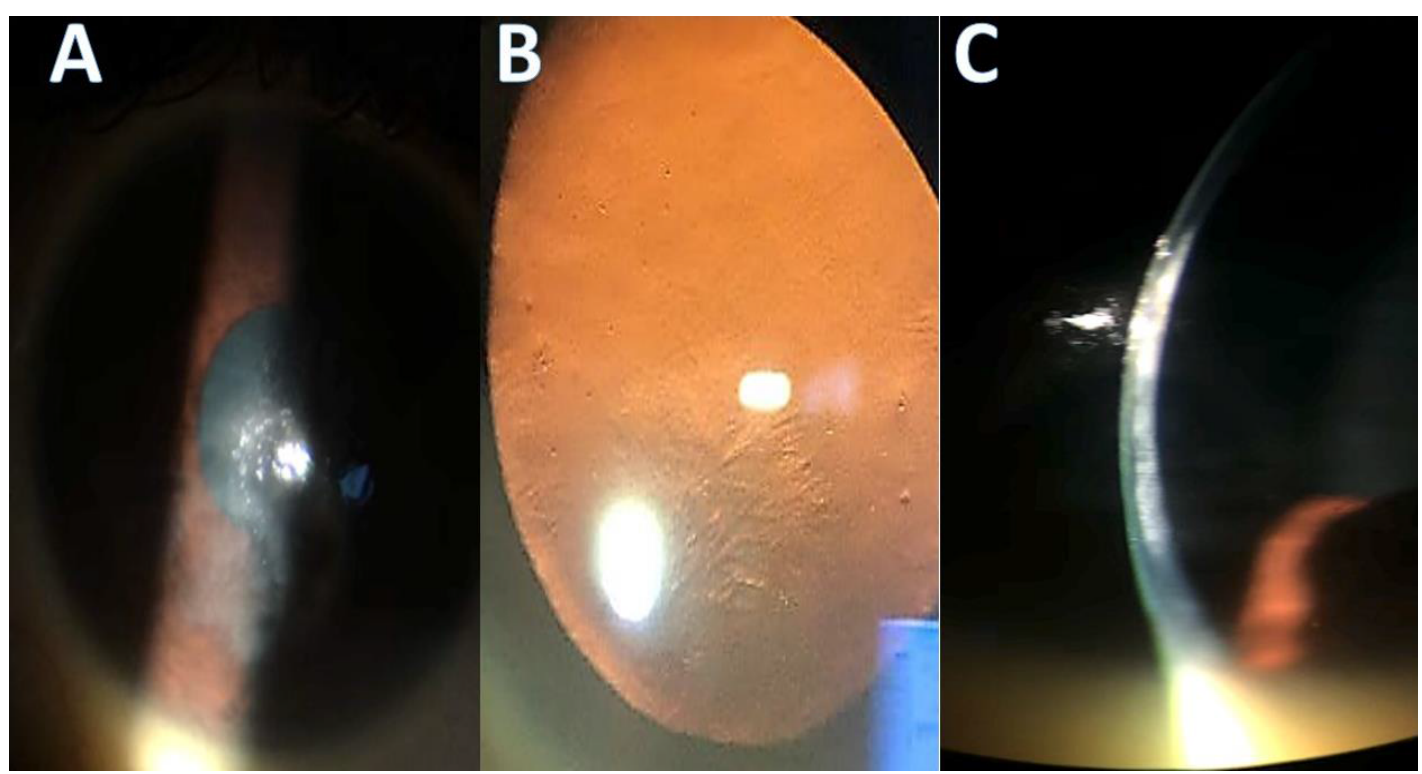

Figure 1: Slit lamp photo of right eye showing stromal opacity (A and B) and branching pattern of ghost vessels (A and C).

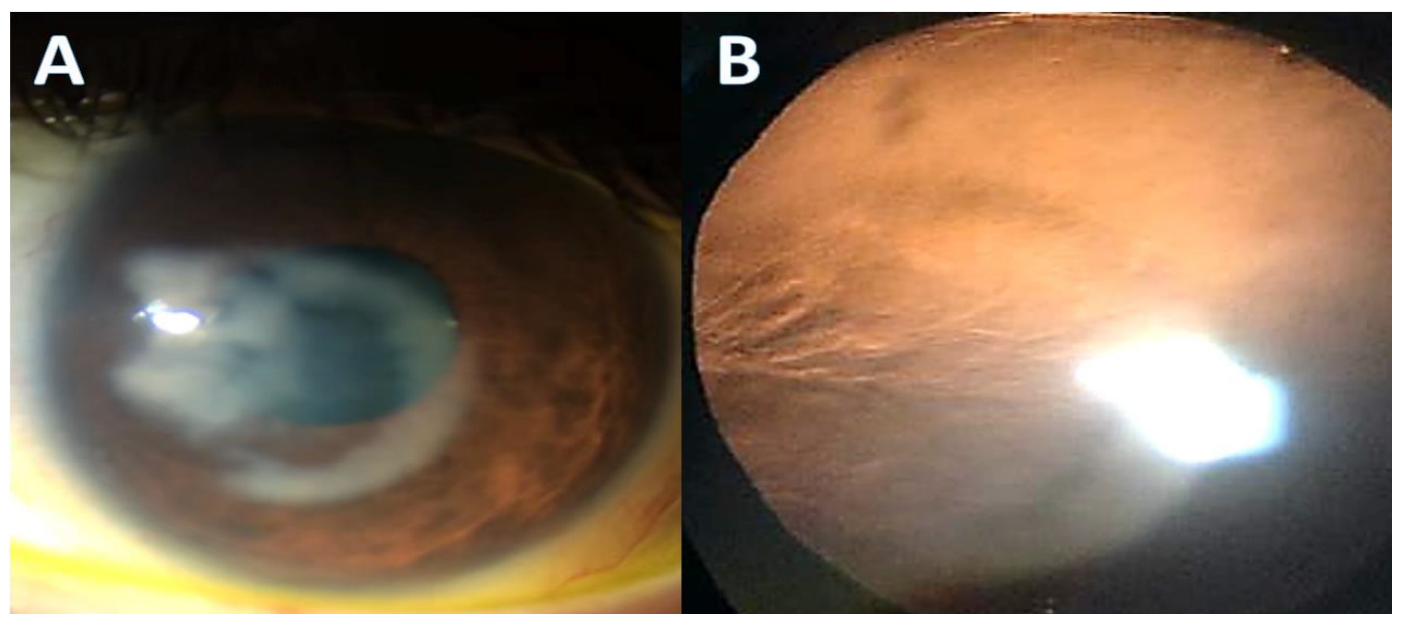

Figure 2: Slit lamp photo showing ring pattern stromal infiltrate $(A)$ with nasal ghost vessels on retroillumination (B).

The right cornea had a round, inferior stromal opacity measuring $4 \mathrm{~mm}$ in diameter, with overlying branching ghost vessels (Figure 1A) located predominantly in the posterior stroma (Figure 1C). Retroillumination showed a branching pattern of the ghost vessels (Figure 1B). The left cornea had a central ring-like stromal opacity with intervening clear cornea (Figure 2A) and a branching pattern on retro-illumination (Figure $2 B$ ).

Given her presentation, systemic work up was performed with complete blood count with differential, erythrocyte sedimentation rate (sed rate), syphilis IgG/ IgM, lyme enzyme immunoassay, early EBV serology, rheumatoid factor immunochemistry, tuberculosis and human immunodeficiency virus serology, and angiotensin converting enzyme (ACE) levels. The patient was found to have anti-EBV early antigen antibodies and mild elevation of sed rate $(27 \mathrm{~mm} / \mathrm{h})$. The remaining blood work was within normal limits. The patient was treated with $1 \%$ topical prednisolone four times daily.

Patient presented for one month follow up and her
BCVA improved to 20/25 bilaterally. The right corneal lesion had a similar presentation but increased in size to $5.4 \mathrm{~mm}$ (height) by $5.2 \mathrm{~mm}$ (width). The left corneal central ring-like stromal opacity began to extend centrally and increased to $4.5 \mathrm{~mm}$ (height) by $4.2 \mathrm{~mm}$ (width). $1 \%$ topical prednisolone drops were slowly tapered over the next 3 weeks; however, patient was lost to follow up.

\section{Review of Cases}

Fourteen additional cases of IK secondary to EBV were identified in the literature. The average age of the 15 patients was 26.58 years, with a median of 20 years of age (Figure 3). The youngest patient was 21-monthsold, and the eldest was 84-years-old. Nine patients were female $(60 \%)$ and six were male $(40 \%)$. Nine patients presented with bilateral corneal involvement (60\%), while 6 patients presented with unilateral involvement (40\%) [4-9].

The ocular manifestations of EBV IK may assume distinct patterns on physical examination. Eight patients presented with discrete, noticeably demarcated, 


\section{Age Distribution of EBV Interstitial Keratitis}

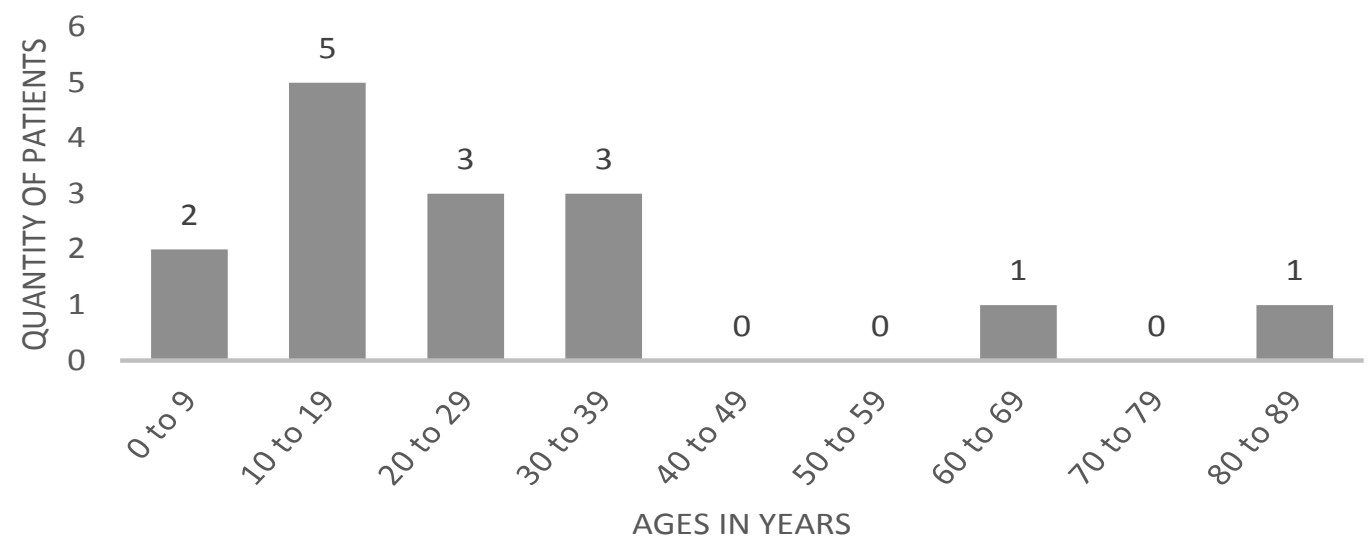

Figure 3: The age distribution of patients diagnosed with interstitial keratitis secondary to Epstein-Barr virus infection.

multifocal, pleomorphic or nummular coarse anterior stromal obscurities with unaffected intervening stroma $[5,6,8,9]$. Three patients presented with multifocal, pleomorphic, full- thickness corneal infiltrates with or without minimal neovascularization [4,5]. One individual presented with both multifocal, pleomorphic, anterior stromal opacities with coarse granularity as well as confluent clusters of opacities [5]. Another case presented with anterior stromal ring-shaped white opacities in the peripheral cornea, which then progressed to confluent peripheral full-thickness white opacities with $360^{\circ}$ intrastromal vascularization [4]. Another interesting case was reported after cataract surgery in which a patient presented with corneal edema and Descemet membrane folds without any evidence of subepithelial infiltrates [7].

Various treatment modalities were used in patients with confirmed IK secondary to EBV. These include corticosteroid drops (prednisolone, dexamethasone, and fluorometholone), antivirals (ganciclovir, acyclovir, and trifluorothymidine), tarivid, artificial tears, and observation alone. Among the 11 patients in the literature treated with ophthalmic corticosteroids, all showed a certain degree of improvement during their treatment course. Eight patients had complete resolution of ocular manifestations and improvements in uncorrected visual acuity without recurrence in symptoms at follow up. One of the remaining patients was adjunctively treated with trifluridine and showed improvement on the treatment regimen. Another patient initially on topical steroids showed lesion progression as well as subsequent involvement of the contralateral eye. He was then treated with oral ofloxacin followed by ganciclovir with complete resolution of the corneal opacity. The last of the three patients that did not experience sustained resolution of EBV IK improved with prednisolone 1\% drops after a failed trial of trifluorothymidine. However, the patient later experienced recurrence of IK in the right eye, which improved with oral acyclovir 1 gram per day for six months [4-9].

Three patients with EBV IK were not treated with corticosteroids. One patient underwent observation alone and had complete resolution after 3 months. Another was treated with artificial tears alone and experienced resolution of symptoms after 6 months, with no recurrences at four years. The last patient was placed on systemic and topical acyclovir therapy, which resulted in a significantly diminished inflammatory response; however, patient was lost to follow up $[5,7]$.

EBV IK was confirmed in patients using a variety of serological studies. Reverse transcriptase polymerase chain reaction (RT-PCR) was performed in three patients: one had a negative RT-PCR despite clinical manifestations of infectious mononucleosis and IK; another had positive RT-PCR in the left eye despite being symptomatic bilaterally; RT-PCR confirmed EBV DNA in the third patient after a positive EBV antigen was detected. EBV specific antiviral capsid antigen (anti-VCA) IgG antibodies were tested in 11 patients, all with positive results. Additionally, anti-EBV nuclear antigen (EBNA) antibody was tested in 7 patients, all with positive results. Anti-EBV early antigen (EBEA) antibody was tested in 2 patients, both with positive results. For one patient, who had a positive heterophile antibody test, the indirect fluorescent antibody technique was used to identify a positive EBV titer. EBV was confirmed as the source for interstitial keratitis in all but one patient using these methods. Our patient was positive for EBEA antibody. Infectious agents ruled out in the literature included syphilis, HSV, adenovirus, CMV, VZV, mumps virus, RSV, and influenza virus [4-9] (Table 1).

\section{Discussion}

EBV is a common infection worldwide with a lifetime prevalence of $90 \%$, with the majority of EBV-related disease in children and young adults [1,4]. In fact, 
Table 1: Overview table with reported cases of interstitial keratitis secondary to Epstein-Barr virus.

\begin{tabular}{|c|c|c|c|c|c|c|c|c|}
\hline $\begin{array}{l}\text { Case Series } \\
\text { (reference) }\end{array}$ & $\begin{array}{l}\text { Number } \\
\text { of } \\
\text { Cases }\end{array}$ & Laterality & $\begin{array}{l}\text { Anterior } \\
\text { Examination }\end{array}$ & Virology & Sex & $\begin{array}{l}\text { Median } \\
\text { Age }\end{array}$ & Treatment & Resolution \\
\hline $\begin{array}{l}\text { Palay, et al. } \\
\text { [4] }\end{array}$ & 1 & Bilateral & $\begin{array}{l}\text { Confluent full- } \\
\text { thickness stromal } \\
\text { opacities with } \\
360^{\circ} \text { intrastromal } \\
\text { vascularization }\end{array}$ & $\begin{array}{l}\text { Anti-VCA } \\
\lg (+) ; \\
\text { EBNA }(+) ; \\
\text { EBEA }(+)\end{array}$ & $M$ & $21 \mathrm{MO}$ & $\begin{array}{l}\text { Topical } \\
\text { corticosteroids }\end{array}$ & Yes \\
\hline $\begin{array}{l}\text { Matoba, et } \\
\text { al. [5] }\end{array}$ & 7 & $\begin{array}{l}2 \text { Bilateral; } \\
5 \text { Unilateral }\end{array}$ & $\begin{array}{l}\text { Multifocal, } \\
\text { pleomorphic } \\
\text { anterior stromal } \\
\text { obscurities with } \\
\text { clear intervening } \\
\text { with minimal } \\
\text { neovascularization }\end{array}$ & $\begin{array}{l}(+) \\
\text { monospot } \\
(1 \text { case); } \\
(+) \text { anti- } \\
\text { viral } \\
\text { capsid (1 } \\
\text { case); (+) } \\
\text { anti-VCA } \\
(6 \text { cases); } \\
(+) \text { EBNA } \\
(3 \text { cases) }\end{array}$ & $\begin{array}{l}4 \mathrm{~F} \\
3 \mathrm{M}\end{array}$ & $14.71 \mathrm{YO}$ & $\begin{array}{l}\text { Prednisolone, } \\
\text { dexamethasone, } \\
\text { artificial tears, } \\
\text { fluoromethalone }\end{array}$ & $3 / 7$ \\
\hline $\begin{array}{l}\text { Pinnolis, et } \\
\text { Al. [6] }\end{array}$ & 1 & Bilateral & $\begin{array}{l}\text { Numerous } \\
\text { nummular stromal } \\
\text { opacities }\end{array}$ & $\begin{array}{l}(+) \\
\text { monospot; } \\
(+) \text { EBV } \\
\text { indirect } \\
\text { fluorescent } \\
\text { antibody } \\
\text { titer }\end{array}$ & M & $16 \mathrm{YO}$ & $\begin{array}{l}\text { Oral prednisone, } \\
\text { prednisolone } 1 \% \\
\text { drops }\end{array}$ & Yes \\
\hline $\begin{array}{l}\text { Wong, et al. } \\
\text { [1] }\end{array}$ & 1 & Bilateral & $\begin{array}{l}\text { Peripheral keratitis } \\
\text { with corneal } \\
\text { stromal edema } \\
\text { and confluent } \\
\text { areas of white } \\
\text { opacities }\end{array}$ & $\begin{array}{l}(-) \\
\text { common } \\
\text { viral } \\
\text { nucleic } \\
\text { acids RT- } \\
\text { PCR }\end{array}$ & M & $30 \mathrm{YO}$ & $\begin{array}{l}\text { Topical acyclovir } \\
\text { ointment adjunct } \\
\text { to systemic } \\
\text { acyclovir; topical } \\
\text { steroid }\end{array}$ & Yes \\
\hline Ding, et al, [7] & 1 & Bilateral & $\begin{array}{l}\text { Corneal edema } \\
\text { and Descemet } \\
\text { membrane folds }\end{array}$ & $\begin{array}{l}(+) \text { RT- } \\
\text { PCR tear } \\
\text { film for } \\
\text { EBV }\end{array}$ & $\mathrm{F}$ & $84 \mathrm{YO}$ & $\begin{array}{l}\text { Artificial tears, } \\
\text { ganciclovir eye } \\
\text { drops, } \\
\text { flumetholon, } \\
\text { tarivid }\end{array}$ & Yes \\
\hline $\begin{array}{l}\text { Matoba } \\
\text { and Jones, et } \\
\text { al. [8] }\end{array}$ & 2 & $\begin{array}{l}1 \text { Bilateral; } \\
1 \text { Unilateral }\end{array}$ & $\begin{array}{l}\text { Multifocal } \\
\text { subepithelial } \\
\text { infiltrates with } \\
\text { intraepithelial } \\
\text { granularity }\end{array}$ & $\begin{array}{l}(+) \text { anti- } \\
\text { VCA IgG } \\
(\text { both } \\
\text { cases); (+) } \\
\text { EBNA (1 } \\
\text { case) }\end{array}$ & $2 \mathrm{~F}$ & $29.5 \mathrm{YO}$ & $\begin{array}{l}\text { Topical } \\
\text { flurometholone } \\
0.1 \% \text {, } \\
\text { prednisolone } 1 \% \\
\text { drops }\end{array}$ & Yes \\
\hline
\end{tabular}




\begin{tabular}{|c|c|c|c|c|c|c|c|c|}
\hline $\begin{array}{l}\text { Matoba, et } \\
\text { al. [5] }\end{array}$ & 1 & Bilateral & $\begin{array}{l}\text { Recurring multifocal } \\
\text { epithelial } \\
\text { dendrites with } \\
\text { pleomorphic, } \\
\text { nummular opacities } \\
\text { and corneal edema }\end{array}$ & $\begin{array}{l}\text { EBV viral } \\
\text { DNA } \\
\text { detected } \\
\text { by PCR; } \\
\text { confirmed } \\
\text { by } \\
\text { serologies }\end{array}$ & $\mathrm{F}$ & 66 YO & $\begin{array}{l}\text { Trifluorothymi- } \\
\text { dine, } \\
1 \% \text { prednisolone } \\
\text { drops, oral } \\
\text { acyclovir }\end{array}$ & No \\
\hline $\begin{array}{l}\text { Pellerin, et } \\
\text { al. [2] }\end{array}$ & 1 & Bilateral & $\begin{array}{l}\text { Nummular stromal } \\
\text { opacities }+/- \\
\text { intralesional } \\
\text { branching ghost } \\
\text { vessels }\end{array}$ & $\begin{array}{l}(+) \text { EBV } \\
\text { EBEA }\end{array}$ & $\mathrm{F}$ & 39 YO & $\begin{array}{l}1 \% \text { prednisolone } \\
\text { drops }\end{array}$ & Unknown \\
\hline
\end{tabular}

M: Male; F: Female; YO: Years Old; MO: Months Old

$80 \%$ of patients in the study presented with signs and symptoms between the ages of 9 and 30 . IK secondary to EBV has the potential to follow a relapsing-and-remitting pattern, increasing the risk of consequent scarring and visual impairment. Thus, it is crucial to identify this condition and initiate appropriate therapy. Rapid treatment reduces the amount of inflammation that occurs and reduces the likelihood of permanent visual defects [10-12].

There are two stages of interstitial keratitis (IK): An acute phase and a chronic phase. The acute phase presents with the appearance of significant stromal neovascularization and edema [10,11]. Other signs include corneal injection, anterior chamber cells and flare, and fine keratic precipitates on the endothelium $[10,11]$. During the chronic phase, patients may present with deep corneal haze or scarring, thinning of stroma, and the appearance of ghost vessels [10,11].

Since the pathophysiology of IK results secondary to the host's immune response to infectious antigen, the corneal involvement can be variable. Although these typical patterns may account for most cases of IK secondary to EBV, this virus has the potential to appear in other unique patterns. Matoba, et al. described discrete, sharply demarcated, multifocal, pleomorphic or ring-shaped granular anterior stromal opacities with normal intervening stroma [5]. They also described EBV presentations that resembled syphilitic stromal keratitis, presenting with peripheral full-thickness, blotchy, pleomorphic, multifocal infiltrates [5]. In comparison, our patient's physical exam findings were unique, evidenced by a peripherally-located round $4 \mathrm{~mm}$ stromal opacity with an intra-lesional branching pattern in the right eye and central stromal opacity with intervening clear cornea and branching pattern on retro-illumination in the left eye.

Topical corticosteroids appear to be clinically beneficial in the treatment of EBV IK. The majority of patients in the literature treated with topical corticosteroid drops had improvement in the ocular manifestations, and many experienced complete resolution. Corticosteroids work by preventing extravasation of inflammatory cells, fibrin and collagen deposition, and scar formation. Antiviral agents have not yet shown the same outcomes in this patient population $[11,12]$. Of note, two patients had resolution of ocular involvement with conservative measures alone. Nonetheless, due to the potential of poor visual outcomes of untreated IK, it is important to consider prompt treatment to prevent corneal scarring [10-12].

Evidence of acute infection with EBV demonstrates increased IgM and IgG antibody levels against viral capsid antigen (VCA) and IgG to EBV early antigen, whereas EBV nuclear antigen (EBNA) antibodies take weeks or months to appear [8]. Antibodies to EBV early antigens generally persist for a few months $[8,13,14]$. Thus, the appearance of antibodies to early antigen is indicative of acute infection; however, the persistence of elevated levels may also be a sign of chronic infection [8]. Conversely, antibodies to VCA and EBNA remain detectable and are indicative of previous EBV infection. If there are increased levels of VCA antibodies with non-detectable or at least fourfold increase in EBNA antibodies, recent EBV infection is probable [8]. Previous research has suggested that the EBV viral load detection in tears has relatively low yield $[15,16]$. EBV DNA has been identified in healthy ocular cells and fluids without any indications of active disease. It is believed that nearby damaged cells may release EBV DNA as a result of intraocular inflammation $[15,16]$. Consequently, EBV genome identified by conventional qualitative PCR should be confirmed with quantitative PCR to assess whether intraocular viral replication is occurring or not $[15,16]$.

Cogan syndrome (CS) may also cause IK and must be considered in the differential. CS is an idiopathic chronic inflammatory disorder that also affects young adults $[17,18]$. This syndrome presents with bilateral IK and vestibuloauditory dysfunction $[17,18]$. On physical exam, CS displays peripheral irregular, granular infiltrates predominately affecting the posterior cornea [18-21]. 


\section{Conclusion}

Although EBV is widespread and most adults have developed antibodies to EBV at some point in their lives, it is a relatively rare cause of IK compared to syphilis and HSV $[1,3]$. The majority of EBV-related IK reported in the literature is documented in young patients. Serology antibody test followed by virology PCR helps establish the diagnosis. Corticosteroids have remained first-line for many forms of IK, including EBV [12].

\section{References}

1. Wong KW, D'Amico DJ, Hedges TR, Soong HK, Schooley RT, et al. (1987) Ocular Involvement Associated With Chronic Epstein-Barr Virus Disease. Arch Ophthalmol 105: 788-792.

2. Tu E, Feldman B, Rose L, Karakus S, Bunya V (2020) Interstitial Keratitis. EyeWiki.

3. Perez V (2017) Interstitial keratitis.

4. Palay DA, Litoff D, Krachmer JH (1993) Stromal Keratitis Associated With Epstein-Barr Virus Infection in a Young Child. Arch Ophthalmol 111: 1323-1324.

5. Matoba AY, Wilhelmus KR, Jones DB (1986) Epstein-Barr viral stromal keratitis. Ophthalmology 93: 746-751.

6. Pinnolis M, McCulley JP, Urman JD (1980) Nummular keratitis associated with infectious mononucleosis. Am J Ophthalmol 89: 791-794.

7. Ding T, Chou Y, Jiang X, Qiu W, Shi D, et al. (2018) A case of blurred vision and viral keratitis postcataract surgery. Future Virology.

8. Matoba AY, Jones DB (1987) Corneal subepithelial infiltrates associated with systemic Epstein-Barr viral infection. Ophthalmology 94: 1669-1671.

9. Pflugfelder SC, Huang A, Crouse C (1990) Epstein-Barr Virus Keratitis After a Chemical Facial Peel. Am J Ophthalmol 110: 571-573.
10. Bagheri N, Wajda B (2017) The Wills Eye Manual: Office and Emergency Room Diagnosis and Treatment of Eye Disease. ( $7^{\text {th }}$ edn), Wolters Kluwer.

11. Gauthier AS, Noureddine S, Delbosc B (2019) Interstitial keratitis diagnosis and treatment. J Fr Ophtalmol 42: e229-e237.

12. Austin A, Lietman T, Rose-Nussbaumer J (2017) Update on the Management of Infectious Keratitis. Ophthalmology 124: $1678-1689$.

13. Horwitz CA, Henle W, Henle G, Rudnick H, Latts E (1985) Long-term serological follow- up of patients for Epstein-Barr virus after recovery from infectious mononucleosis. J Infect Dis 151: 1150-1153.

14. Davidsohn I (1937) Serologic diagnosis of infectious mononucleosis. JAMA 108: 289-295.

15. Yamamoto S, Sugita S, Sugamoto $Y$, Shimizu N, Morio T, et al. (2008) Quantitative PCR for the detection of genomic DNA of Epstein-Barr virus in ocular fluids of patients with uveitis. Jpn J Ophthalmol 52: 463-467.

16. Usui N (1994) Detection of herpes virus DNA in intraocular tissue. J Jpn Ophthalmol Soc 98: 443-448.

17. Cogan DS (1945) Syndrome of nonsyphilitic interstitial keratitis and vestibuloauditory symptoms. Arch Ophthalmol 33: 144-149.

18. Azami A, Maleki N, Kalantar Hormozi M, Tavosi Z (2014) Interstitial Keratitis, Vertigo, and Vasculitis: Typical Cogan's Syndrome. Case Rep Med 2014:830831.

19. Krachmer JH, Mannis MJ, Holland EJ (2005) Cornea. Philadelphia: Elsevier/Mosby.

20. Sihota R, Tandon R (2015) Parsons Diseases of the Eye. Elsevier, India.

21. Schwartz GS, Harrison AR, Holland EJ (1998) Etiology of Immune Stromal (Interstitial) Keratitis. Cornea 17: 278-281. 